\title{
Verdad e imagen: la edición en las representaciones fílmicas del Holocausto
}

institucional.us.es/ambitos/

\section{Aarón Rodríguez Serrano}

Universidad Europea de Valencia

aaron_stauff@hotmail.com

\section{Resumen}

El presente trabajo pretende profundizar en la problemática teórica derivada de las decisiones en la edición de películas relacionadas con el Holocausto. Se parte de un aparataje bibliográfico que apuesta por las posibilidades de la representación de la

Shoah para encarar tres problemas bien definidos: las relaciones entre edición, representación y verdad mediante el uso del plano secuencia, la mostración de las cámaras de gas $\mathrm{y}$, por último, la inserción de imágenes de archivo en un contexto

ficcional. Tras la exposición teórica se realizará un breve análisis textual de diferentes trabajos contemporáneos que permitan ver cómo el cine ha respondido a

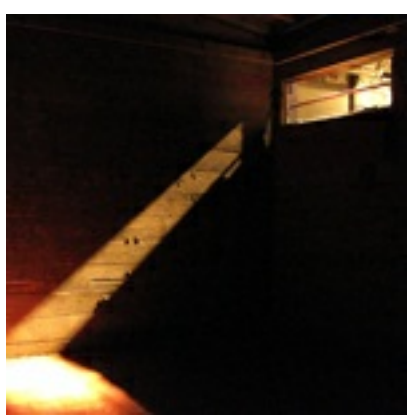
dichos retos durante los últimos quince años.

\author{
Palabras clave \\ Holocausto, Cine, Edición, Representación, Montaje.
}

\section{Abstract}

This paper is focused on the theorical problems related to the editing in the holocaust movies. Our methodological and bibliographical tools try to defend the possibilities of the Shoah's representation in order to focus three main and well-defined problems: the connections between editing, representing and saying the truth by the use of the sequence shot, the gas chambers'showing and the insertion of historical footage in a fictional context. After the theoretical explanation, we will develop a brief textual anaylse of different contemporary works who will allow us to see how the cinema has been facing this issues during the last fifteen years.

\section{Keywords}

Holocaust, Cinema, Editing, Representation, Cutting.

\section{INTRODUCCIÓN}

A principios de Abril de 1945, SidneyBernstein -el jefe de la sección audiovisual de la PsychologicalWarfareDivision of the Supreme Headquarters Allied Expeditionary Force (SHAEF) británica-, visitó el campo de Belsen para proponer un documental en colaboración con el

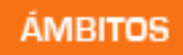

2014 $n^{2} 26$ ejército soviético dedicado a difundir las atrocidades nazis cometidas en los campos de concentración y exterminio. Ante la magnitud de las imágenes registradas en directo por los operadores, Bernstein buscaba a alguien capaz de "aderezar (flavour) un metraje tan controvertido, y a su vez, proceder con la necesaria cautela” (Jacobs, 2011: 268).

En aquellos días finales de la guerra, las imágenes de los campos ya eran prácticamente de dominio público en los países aliados. Se habían ido incorporando paulatinamente en los noticiarios e incluso se encontraban en un avanzado estado de desarrollo varias grandes ediciones previas de larga duración, entre las que destacan Nazi concentrationcamps (George Stevens, 1945), orientada al público norteamericano, y Die Todesmühlen (Hans Berger, 1945), especialmente realizada para ser exhibida en los territorios alemanes ocupados por los aliados. La primera proyección de una bobina completa tuvo lugar el 26 de Abril en el cine Embassy de Nueva York. Sin embargo, estas primeras experiencias de exhibición generaron un extraño efecto: una parte de los espectadores, ciudadanos aliados, afirmaron "no creerse el contenido de las imágenes" (Haggith, 2005: 45) o 
considerar de mal gusto su inclusión "antes de disfrutar de un cortometraje animado del Pato Donald" (Struk, 2004: 127). Dos rasgos parecían dominar el contenido significante de estas imágenes: de un lado, su extraña falta de verosimilitud, y de otro, la necesidad que parecían exigir de ser llevadas más allá de los circuitos convencionales. Las imágenes de los campos provocaban un cortocircuito interior (ya sea por la vía del rechazo o de la fascinación) y un efecto de contagio contra las imágenes que eran proyectadas junto a ellas.

Bernstein, como decíamos, era consciente de la problemática que encerraban estas imágenes y quiso encontrar un asistente para el montaje que estuviera acostumbrado a bregar con contenidos significantes remotamente afines: el cadáver, el asesinato, el horror. Su elección recayó sobre Alfred Hitchcock, que tras visionar las imágenes, generó un documento de trabajo para el equipo de montaje basado en una lógica básica: contextualizar, evitar a toda costa la fragmentación y beneficiar siempre que fuera posible la inclusión de tomas largas (Sussex, 1984: 96).

En cierto sentido, podíamos pensar que Hitchcock había intuido ya en 1945 lo que posteriormente se convertirá en la piedra de toque de la reflexión teórica de André Bazin -y por lo tanto, de la modernidad fílmica:

Si nos esforzamos ahora en definir la dificultad, me parece que se podría plantear como ley estética el siguiente principio: "Cuando lo esencial de un suceso depende de la presencia simultánea de dos o más factores de la acción, el montaje está prohibido". Y vuelve a recuperar sus derechos cada vez que el sentido de la acción no depende de la contigüidad física, aunque esté implicada (2001: 77).

Merece la pena detenerse, aunque sea brevemente, en la cita baziniana para ver las enormes dificultades que implica en su aplicación a la narración de los campos. La pregunta que tuvieron que intentar responder los cámaras $-\mathrm{y}$, posteriormente, los editores- de las imágenes retratadas en Bergen Belsen fue, precisamente: ¿dónde está lo esencial del horror que debe ser mostrado? Y, llegando todavía más lejos: ¿es posible imaginar una grabación en los campos en la que el sentido de la acción no dependa necesariamente de la contigüidad física?

La fórmula baziniana nos lleva directamente a un callejón sin salida: la única posibilidad estética de contar Bergen Belsen bajo su ley es un interminable plano-secuencia que recorriera aquellos puntos topográficos en los que se encuentra lo esencial. Ahora bien, si tuviéramos la ocasión de analizar las recreaciones audiovisuales de los campos, veríamos cómo para cada realizador lo esencial se encuentra absolutamente dislocado. Volveremos sobre esta idea más adelante. Por el momento, baste con señalar que tanto Hitchcock como Bazin coincidieron en una idea: la ausencia de montaje implica, de alguna manera, una cierta verdad en la recepción de las imágenes. O, como lo resumió Ángel Quintana:

Lo importante de la imagen, no son, para André Bazin, los valores significantes que ésta añade a la realidad, sino que aquello que revela la verdad de las cosas. La imagen debe ser vista como un instrumento útil para el conocimiento que la consciencia posee de los datos que componen la realidad empírica (Quintana, 2003: 128).

El problema de ésta fórmula, por supuesto, es pretender que hay una hipotética verdad que puede ser revelada por la imagen, o en el límite, que la imagen por sí misma es capaz de revelar verdad alguna. Y, por extensión, añadir que el montaje atora o complica esa realidad mediante un ejercicio de construcción de discurso. Para proponer un primer acercamiento a esta idea, encararemos tres problemas y utilizaremos, en cada caso, un breve fragmento de una cinta contemporánea de ficción que explore las resonancias que nos sugiere. Así, propondremos una cierta duda sobre qué significa hablar de Verdad y Holocausto con relación a la utilización del plano secuencia y el montaje interno -con el cierre de la cinta Good (Vicente Amorin, 2008)-, posteriormente encararemos la posible mostración de las cámaras de gas mediante dos estrategias enunciativas distintas en la misma película -en La zona gris (Tim Blake Nelson, 2001)-, y por último, reflexionaremos brevemente sobre el montaje de imágenes de archivo en Auschwitz (UweBoll, 2011). Nuestra metodología, por lo tanto, partirá de un doble movimiento: de una lectura crítica sobre la teoría tradicional de la mostración holocáustica al análisis fílmico, intentando proponer un punto de vista innovador en defensa de la mostración y la posibilidad de un decir en la imagen holocáustica.

\section{LA VERDAD Y EL HOLOCAUSTO}


Aunque, como bien ha demostrado Sánchez-Biosca (1996: 45), Bazin no negara radicalmente la posibilidad de un montaje, sí que es cierto que generó una serie de complicadas torsiones teóricas que acabarían por definir la problemática de la mostración del Holocausto en la modernidad (Font, 2002: 160-167). La posibilidad de que la imagen nos permita llegar a la verdad parece enfrentarse de manera denodada con ciertos límites que la filosofía ya había superado varios años atrás, desde que Kierkegaard señaló por vez primera la imposibilidad total del ser humano de conocer la verdad por sí mismo, sin la ayuda de Dios (Kierkegaard, 1997: 27-37). Nuestra imposibilidad de adquirir una verdad total corre en paralelo a la llamada "crisis del sujeto", y en consecuencia, nos posiciona en el corazón del vértigo relativista.

En el caso concreto de la representación del Holocausto, este punto de vista se ha traducido en dos grandes adjetivos que hasta hace muy poco dominaban la práctica totalidad de sus reflexiones: la inefabilidad y la irrepresentabilidad (Reyes Mate, 2003; Sánchez-Biosca, 2006). Ambas ideas partían de las airadas declaraciones de dos teóricos que, a su vez, habían generado dos escuelas paralelas a ambos lados del atlántico: ElieWiesel (1) en Estados Unidos y Claude Lanzmann (2003 y 2011) en Europa. El hecho de la inefabilidad o de la imposibilidad de su comprensión se entendió desde un primer momento como una garantía de la unicidad y la especificidad del Holocausto, generando una suerte de contradicciones teóricas que sólo han comenzado a ser subsanadas en los últimos años gracias a autores como AaronKerner (2011), y muy especialmente, Yehuda Bauer (2001: 14-23).

La supuesta inefabilidad del Holocausto es, a la postre, un simple pero efectivo bloqueo teórico ante la imposibilidad de dar ontológica o históricamente una respuesta satisfactoria sobre lo ocurrido. La terrible dificultad de pensar todos los aspectos que lo conforman, desde sus conexiones con la modernidad (Bauman: 2010) hasta la psicología de los verdugos (Goldhagen, 1997; T. Gross, 2001; Browning, 2002), acaba generando un magma de opiniones encontradas, generalmente imbricadas con los problemas de la culpa y la responsabilidad personal, que hacen imposible un tratado "total" de la Shoah. Ni siquiera los célebres e integradores estudios de Hilberg (2005) y Friedländer (2009) son definitivos y ofrecen una explicación total sobre los infinitos matices que componen la verdad de la Shoah.

Resulta, por lo tanto, particularmente extraño, que en un territorio con una historiografía tan desgajada y compleja, se le haya exigido con tanta crudeza a la imagen la capacidad de decir la verdad, o en el límite (Wajcman, 2001), de no decir nada en absoluto. Por supuesto, no pretendemos decir que no se pueda decir la verdad sobre el Holocausto -cosa a todas luces falsa, salvo que el teórico sea un demente o un negacionista-, sino que la imagen y los mecanismos de lenguaje cinematográfico tampoco pueden ofrecer al debate sobre el Holocausto esa verdad absoluta que la historiografía más rigurosa y la filosofía más coherente abandonaron hace décadas. Ese "no poder decir toda la verdad" es, en esencia, un rasgo que el Holocausto comparte -sin ser, por lo tanto, único en este aspecto concreto- con cualquier otro genocidio histórico, y a la postre, con cualquier vivencia del ser humano. Pretender que dos propuestas como S-21: La máquina de matar de los jemeres rojos (S-21, la machine de mortKhmère rouge, RithyPanh, 2003) o Theact of Killing (Christine Cynn, Joshua Oppenheimer y Anónimo, 2012) pueden decir toda la verdad sobre el exterminio camboyano o indonesio, respectivamente, es en ambos casos un tremendo error. De igual manera que el abandono de la Voz de Dios y otros recursos documentales que parecían garantizar de alguna manera la objetividad de la imagen repercutieron en una auténtica revaloración de la subjetividad y la mirada (AAVV, 2007), es hora de que la relación entre memoria, barbarie y cine siga un proceso similar.

La imagen del Holocausto, en tanto no puede decir toda la verdad funciona de otra manera, y quizá nada tan útil como el viejo concepto de la Aletheia heideggeriana (Moreno Claros, 2002: 331-354) para explicar cuál es su posibilidad:

La obra pertenece, en tanto que obra, a aquel otro ámbito que se abre gracias a ella misma, puesto que el ser obra perteneciente a la obra se hace presente en aquella apertura y sólo allí. En ese sentido decíamos que en la obra se pone manos a la obra el acontecimiento de la verdad (Heidegger, 1995: 29).

O como señaló todavía con más claridad Gianni Vattimo en su lectura de los textos sobre las relaciones entre verdad y representaciones artísticas: 
Aun la experiencia estética común encuentra siempre la obra de arte, no como un "objeto" que se pueda colocar en el mundo junto a los otros objetos, sino antes bien como una perspectiva general del mundo que entra en diálogo con nuestra perspectiva y que nos obliga a modificarla, o por lo menos, a profundizarla (2002: 108).

Sólo a partir de esta concepción entre verdad y obra de arte podemos empezar a pensar con cierta fiabilidad en la que el montaje de las imágenes del holocausto puede ayudarnos a comprender, modificar o profundizar nuestra experiencia como sujetos de la barbarie. Pensar que la negación del montaje -por la utilización del plano secuencia- es una garantía de verdad ontológica parece ya, definitivamente, un argumento insostenible y sólo podría mantenerse en tanto la utilización de dicho recurso ofreciera un efecto estético (una impresión de verdad) o que, a su vez, generara una serie de efectos emocionales que nos permitieran acceder a una cierta comprensión -una cierta vivencia, mediada por lo cinematográfico- del Holocausto.

\subsection{Es real: El plano secuencia en Good (Vicente Amorim, 2008).}

El primer ejemplo que nos gustaría traer a colación es la película Good (Vicente Amorim, 2008), que encara un aspecto concreto de la Shoah: la responsabilidad de las universidades y de los científicos en el desarrollo de los campos de exterminio. Sus tesis coinciden con lecturas historiográficas como las de Francisco Morente (2004) o la de Julio Quesada (2008), señalando las conexiones entre el cuerpo docente del momento y su complicidad con el desarrollo de la maquinaria ideológica y técnica que posibilitó el Holocausto. En términos narrativos, la estructura de Good es razonablemente sencilla: focalizando principalmente sobre la figura de un profesor que se desploma en la fascinación por la maquinaria y el pensamiento nazi (ViggoMortensen), Amorim culmina su trayecto en una suerte de anagnórisis siniestra con su llegada a un campo de exterminio.

Si la acción se construye con un montaje más bien convencional, el desvelamiento de la verdad para el protagonista está retratado únicamente mediante un largo plano-secuencia de casi cuatro minutos de duración. A su vez, la extensión del plano se utiliza en tres segmentos claramente diferenciados con diferentes intenciones narrativas. En el primero, el protagonista camina en silencio por lo que parece la avenida principal del campo. La cámara le retrata en una suerte de travelling de seguimiento que beneficia su peso en el relato y que hace que a su alrededor los cuerpos de las víctimas aparezcan como simples borrones, manchas sin personalidad que salpican la escena y que nosotros únicamente localizamos gracias a nuestro conocimiento previo de la iconografía del horror.

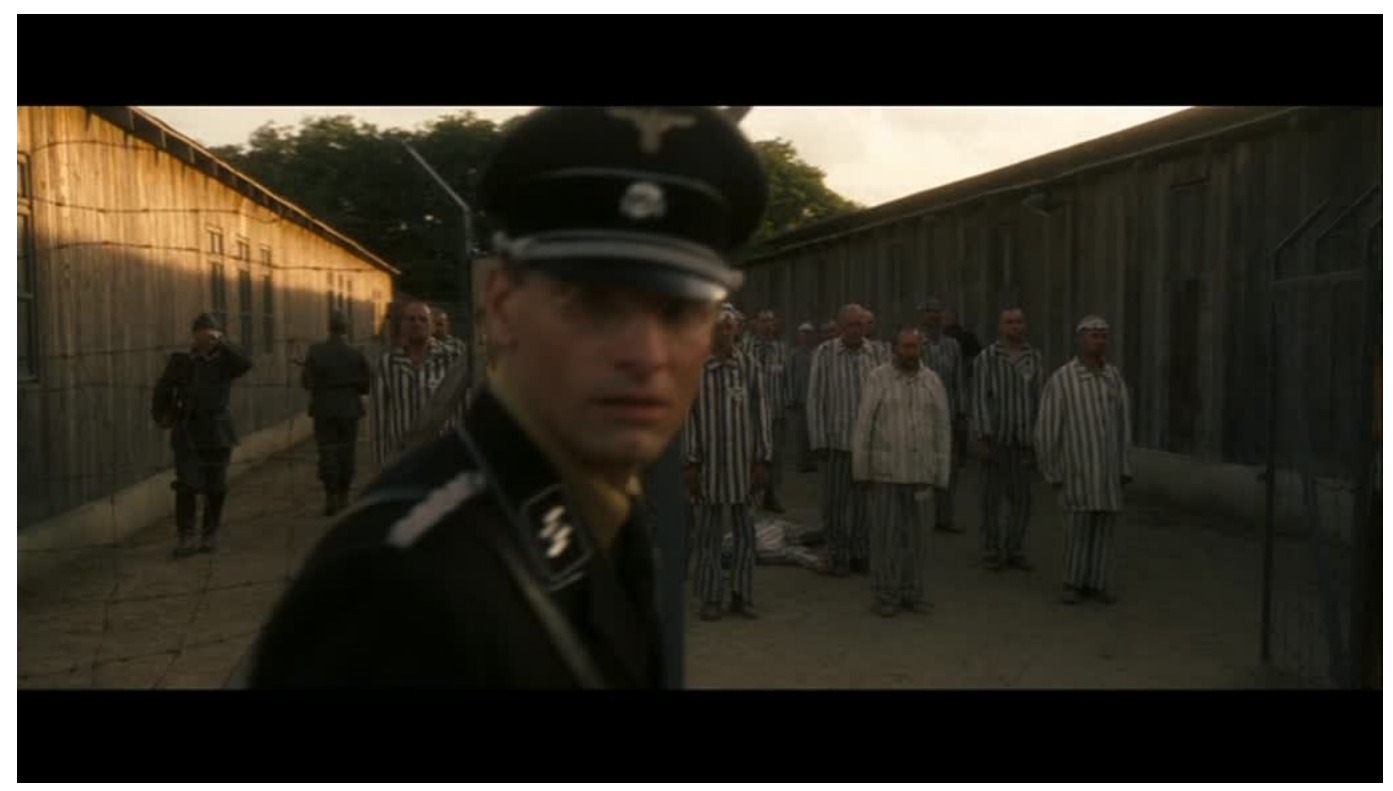




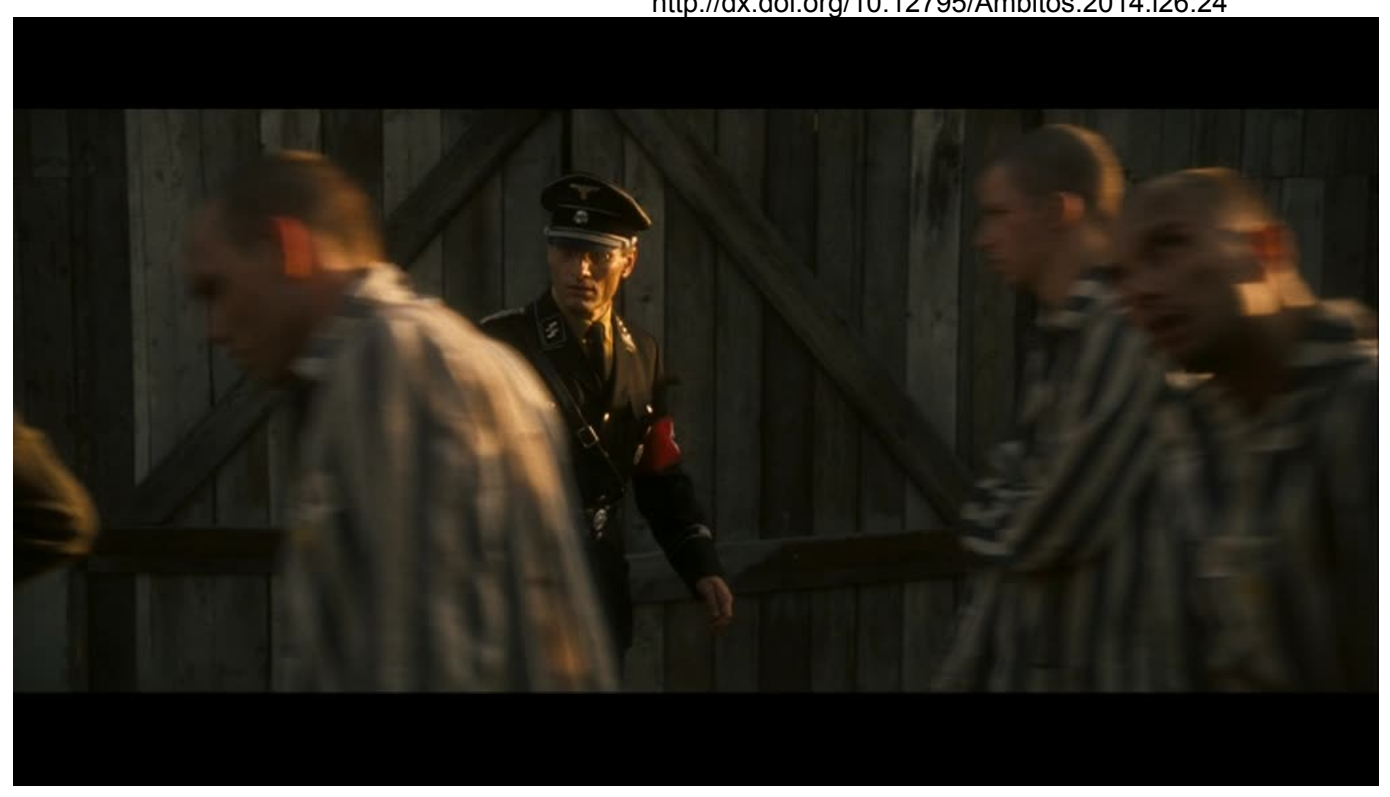

Imágenes 01 y 02: Good (Vicente Amorin, 2008)

En el segundo segmento, Amorin se separa del protagonista para mostrar los primeros -y únicos- rostros de las víctimas que comparecen frente al objetivo de la cámara: los músicos que tocan en la plaza principal del campo. A juzgar por su señalética, la mayoría de ellos son presos políticos, y no judíos, que miran al protagonista con una suerte de expresión confusa. La música sirve como un elemento distanciador, y al mismo tiempo, hilvana una serie de sugerencias con respecto a la psicosis que el director había esbozado en el metraje anterior -una alucinación que acompaña a Mortensen en su desplome. El plano secuencia se convierte, durante algunos segundos, en plano subjetivo al recorrer un arco que coincide con el eje de la mirada del protagonista. Sin embargo, antes de que el espectador se pueda instalar en dicha situación, volvemos en un nuevo movimiento a lo que correspondería con el contraplano de la banda.

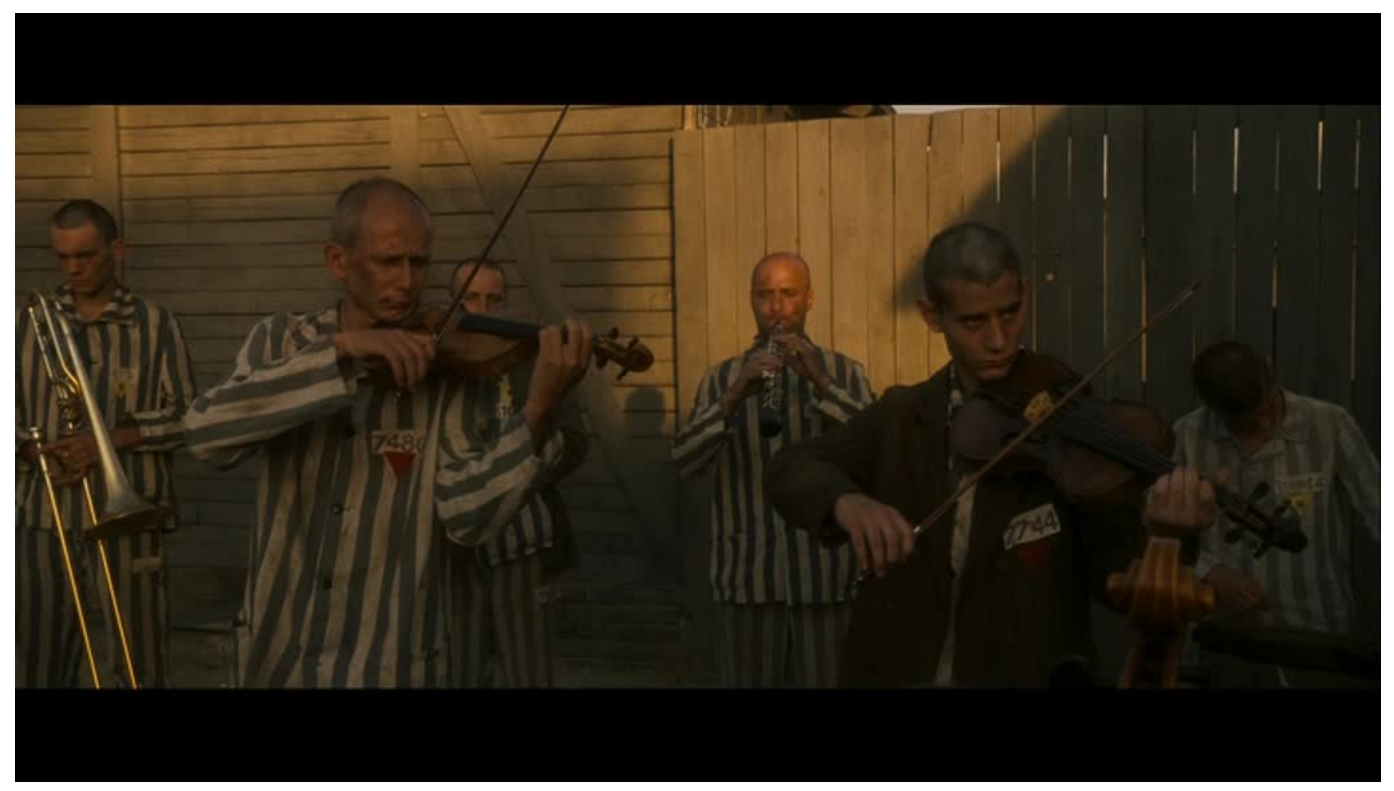




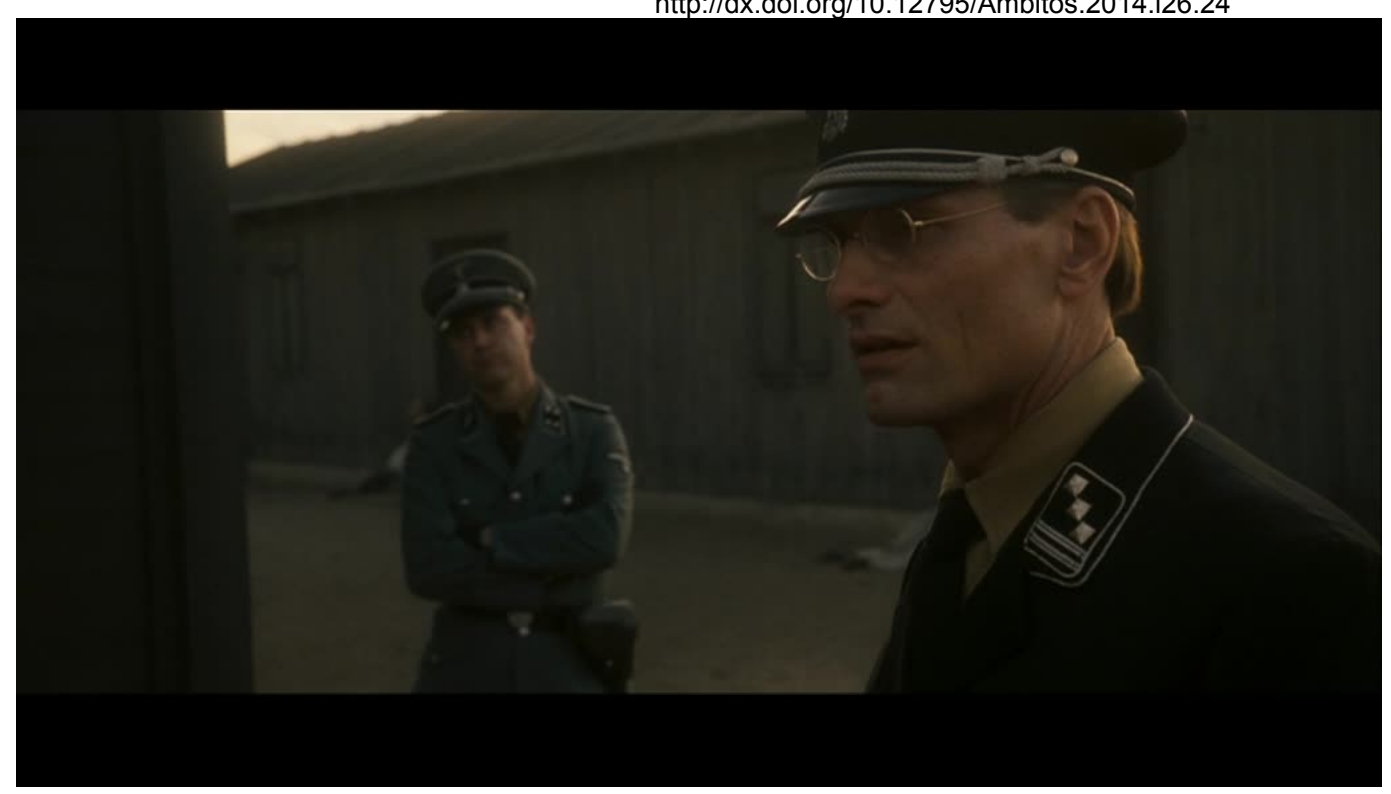

Imágenes 03 y 04: Good (Vicente Amorin, 2008)

Mortensen pronuncia entonces las dos últimas palabras de la película: Es real. Ahora bien, ¿qué es real? ¿El delirio que atenazaba al personaje y que ahora se encarna en esos cuerpos que miran hacia él? ¿El sistema de exterminio, consecuencia última de sus teorías académicas que ahora se encarnan en la topografía del campo? O en el límite, ¿el propio sistema fílmico enunciativo, en el que no hay corte alguno sino que el tiempo -un tiempo del horror- fluye interminablemente dentro del plano?

En cualquier caso, esas dos palabras parecen dar la señal para que la cámara abandone su fascinación con el personaje y se aleje, en un rápido travelling hacia atrás, dejándonos ver un plano general del campo en lo que parece la llegada de un convoy de judíos. Esa última posición de cámara destaca por su gran contenido semántico: utilizando la profundidad del escenario, Amorim divide la franja en tres grandes segmentos: las víctimas -que llegan, sin rostro, de espaldas a la cámara-, los verdugos, y en el fondo, el profesor universitario retratado junto a un edificio que hasta el último momento no se concreta como un crematorio.

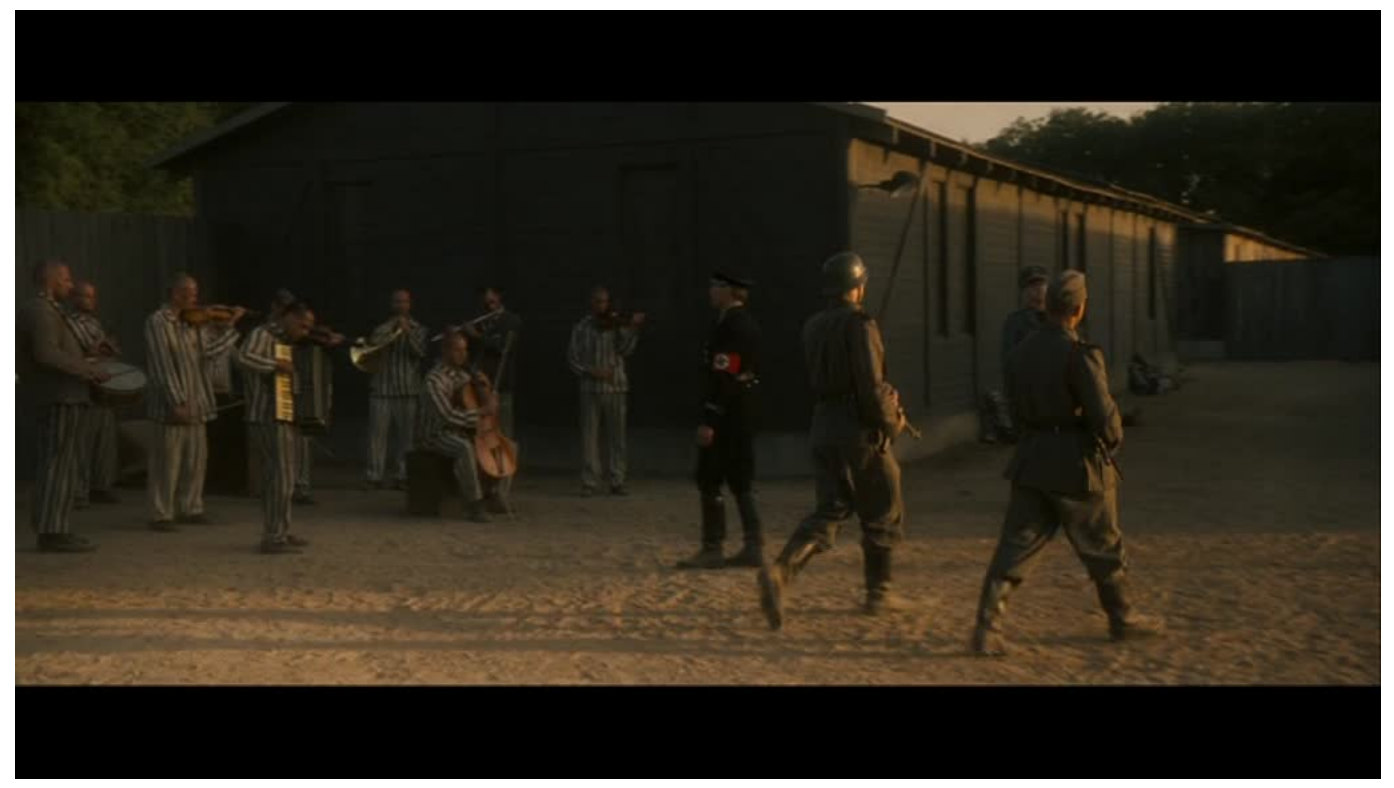




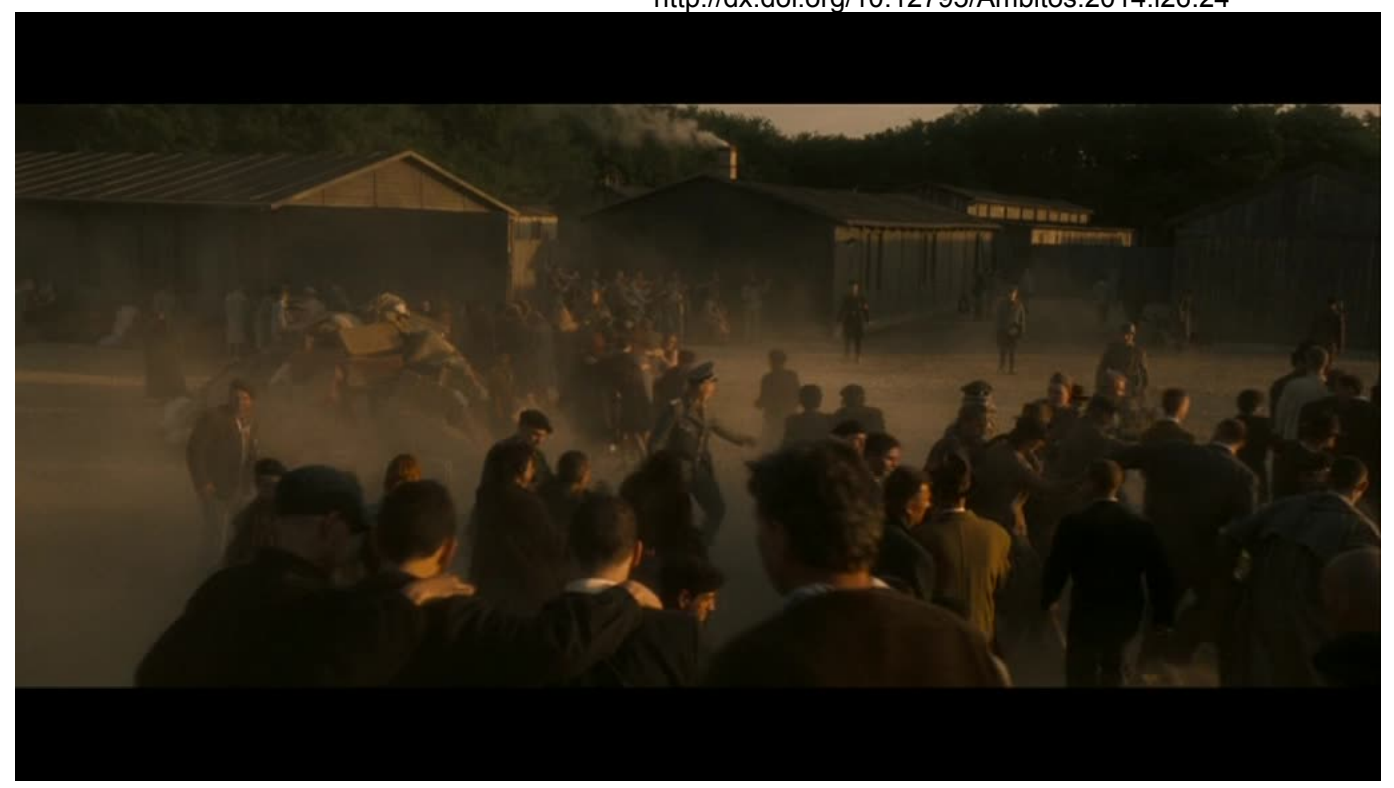

Imágenes 05 y 06: Good (Vicente Amorin, 2008)

El plano secuencia es utilizado, por tanto, no tanto como una garantía de verdad, sino como una posibilidad de traducir en un flujo de tiempo cinematográfico la idea del descubrimiento y el cierre hermenéutico que atraviesa el triángulo de protagonistas propuesto por RaulHilberg (1993): del bystander-representado en la figura de un Mortensen que, simplemente, no quiso ver- a la víctima, atravesado a su vez por la presencia del verdugo. La anagnórisis tiene forma, para Amorin, de recurso cinematográfico, de desplazamiento topográfico en el que la cámara atraviesa -guidada por el cuerpo o por la mirada del protagonista- la avenida principal del campo. En última instancia, el plano secuencia permite además generar dos interesantes fricciones en la focalización. La primera, cuando se genera una confusión entre la mirada de Mortensen y la del propio espectador en ese falso subjetivo, la segunda cuando la cámara se eleva por encima de la línea de visión humana y se posiciona en un picado ligeramente superior que coincide con una entidad casi teológica, o en el límite, con la propia presencia del enunciador clausurando el relato.

Por lo tanto, este tipo de recurso tiene un sentido no tanto en sí mismo, sino en la relación que establece con la cadena de significación textual de montaje que se ha desplegado durante la hora y media anterior. Y tiene un sentido -de descubrimiento- únicamente desde la lógica heideggeriana, una lógica de la incompletud de la perspectiva de la obra de arte que discute con la perspectiva histórica (la perspectiva de la verdad a la que no podemos llegar), y también la perspectiva del espectador. En esta dirección, podemos seguir avanzando al recordar las hermosas palabras sobre el montaje que propuso Kracauer, el otro gran defensor del realismo junto a Bazin:

Un principio básico del montaje: cualquier narración cinematográfica debe ser montada de manera tal que no se limite simplemente a desarrollar la intriga, sino que además se aparte de ésta para apuntar hacia los objetos representados, con el fin de que aparezcan en toda su sugestiva indeterminación (Kracauer, 2001: 102).

\section{LA SUGESTIVA INDETERMINACIÓN DE LAS CÁMARAS DE GAS}

Uno de los problemas mayores en las representaciones del Holocausto es la mostración del interior de las cámaras de gas. Las estrategias en su tratamiento han sido hasta hace muy poco de lo más pintorescas: o el borrado completo de su presencia icónica en los textos holocáusticos -generalmente mediante una serie de elementos simbólicos que servían como significantes desplazados (2): la chimenea de los crematorios, el humo de los trenes o de las fábricas...- o bien la detención de la representación a las puertas de las mismas. En algunos casos -por ejemplo, en Amen (Costa-Gavras, 2002)- se juega con la mirilla de las puestas como una suerte de operador textual: hay un camino hacia la visión, hay un aparato que permite la posibilidad de mirar, pero su uso está restringido únicamente a una serie de personajes. En su lugar, la planificación se detiene generando un inmenso campo vacío que, como mucho, se sugiere mediante el sonido off de los gritos de las víctimas. En líneas generales, en términos de montaje se obligaba a practicar una suerte de elipsis entre la entrada de los cuerpos y su salida, como si ese espacio de varios minutos de muerte y angustia pudiera ser 
pudorosamente extraviado en el juego de las representaciones.

En cierto sentido, no resulta sorprendente que fuera la televisión la primera que prescindiera voluntariamente de ese pudor representativo, al menos en la parte occidental del telón de acero (3). Las dos miniseries Holocaust (NationalBroadcastingCompany, 1978) y War and Remembrance(American BroadcastingCompany, 1988), emitidas en horario de máxima audiencia y con una más que notable aceptación popular, en torno a los 220 millones de personas en todo el mundo (Frodon, 2010,14), generaron una serie de modificaciones no sólo con respecto a la "laxitud" con la que se podían reconstruir los sucesos históricos, sino también sobre lo que resultaba mostrable en la pantalla.

Si bien tanto Holocaust como War and Remebrance aparecen una y otra vez en la bibliografía especializada como dos errores éticos que comenzaron la banalización del Holocausto, durante los últimos años se ha ido generando una mayor tendencia a permitir que el relato se introduzca en la cámara de gas de manera explícita. Y, merece la pena señalarlo, resulta imposible generar ningún tipo de criterio clasificatorio que garantice algún tipo de conclusión teórica: las cámaras de gas se visitan tanto en precisas reconstrucciones con gran respeto historiográfico como La zona gris (The grey zone, Tim Blake Nelson, 2001) o en completos delirios ahistóricos como El niño del pijama a rayas (Theboy in theStriped pijamas, Mark Herman, 2008), en películas hollywoodienses de localización contemporánea como Verano de corrupción (AptPupil, Bryan Singer, 1998) o en pseudo-documentales europeos amarillistas como Auschwitz(UweBoll, 2011)...

La "prohibición" de rodar y editar las cámaras de gas parece, por lo tanto, haberse dejado aparte con un gesto sutil. Todavía no se ha levantado ningún terremoto teórico, ni se ha generado ningún efecto de aberración por parte de la recepción de los relatos del Holocausto. Hay, en cualquier caso, dos datos interesantes que no podemos dejar de señalar. El primero es que el tránsito en la mostración se desarrolla de la televisión al cine, esto es, las imágenes imposibles de las cámaras entran primero en los hogares y, posteriormente, en las salas de cine. El segundo es que, contra lo que parecía obvio y siguiendo a Kracauer, el lenguaje audiovisual dice algo sobre esa sugestiva indeterminación de las cámaras de gas.

Sin embargo, antes de ver qué se dice mediante el montaje, quizá sería coherente despejar un cierto aspecto. Siguiendo con las "normas sobre el montaje" que venimos referenciando en nuestro estudio, no está de más recordar a Didi-Huberman:

El montaje sólo es válido cuando no se apresura demasiado en concluir o en clausurar de nuevo, es decir, cuando inicia y vuelve compleja nuestra aprehensión de la historia, no cuando la esquematiza abusivamente (2004: 180).

El problema del sistema didi-hubermaniano, por supuesto, es qué debemos entender exactamente por "aprehensión" de la historia. Problema relacionado directamente con la imposibilidad de esbozar una única verdad con respecto al Holocausto, como veíamos anteriormente, pero que se enrarece todavía más al hablar de las cámaras de gas. Ciertamente, al "aprehender la historia" debemos pensar que se habla no únicamente de una cierta información técnica o económica sobre el funcionamiento de la maquinaria de la muerte, sino de sus implicaciones personales en la experiencia del espectador. Y, es menester señalarlo, no nos referimos a esa tan cacareada -por imposible- empatía total entre el espectador y la víctima que ya hemos despejado en otro lugar (Rodríguez Serrano, 2012), sino a la experiencia que se vive en el tránsito del relato fílmico.

Una vez más, la experiencia vivida en el filo de la ficcionalización de las cámaras responde a decisiones significantes de montaje, y por lo tanto, a la aportación del objeto textual "cámara de gas" a los acontecimientos relatados. De ahí que, a priori, parezca imposible realizar una generalización sobre la "correcta" inserción de las cámaras de gas en el relato. En el siguiente epígrafe tomaremos dos ejemplos para comparar el uso de las cámaras de gas y analizaremos su función en términos narrativos.

\subsection{Las cámaras de gas en "La zona gris"}

Como señalábamos anteriormente, La zona gris puede ser considerada por derecho propio como una de las cintas más cuidadas en las relaciones entre lo mostrado y los datos disponibles desde la historiografía (4). Su adaptación toma como base las memorias de MiklósNyiszli (2011), aunque se apoya también en los datos 
disponibles sobre la revuelta de los miembros del Sonderkommando en Octubre de 1944 (Swiebocki, 2000: 116-121). El tratamiento narrativo de la función de los Sonderkommando -las unidades de trabajo compuestas por judíos que ejercían su función en el interior de las cámaras de gas y los crematorios- parece exigir, por lo tanto, su mostración en pantalla.

La primera vez que son conjuradas en el relato, llegan hasta nosotros mediante un único plano consistente en una panorámica lateral de izquierda a derecha, en la que los sonderkommandos limpian las paredes con agua:
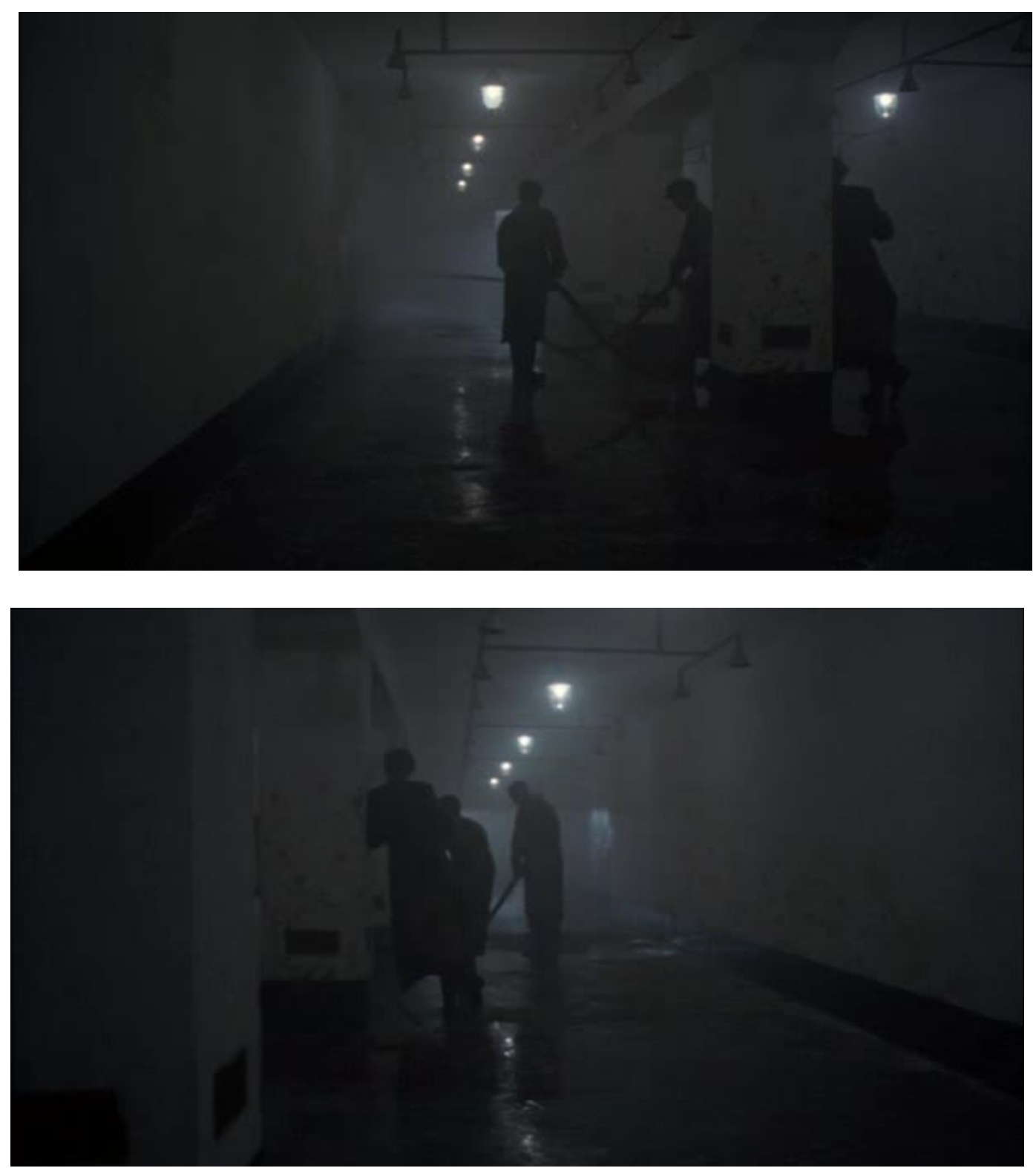

Imágenes 07 y 08: La zona gris (Tim Blake Nelson, 2001)

El corte en montaje se produce inmediatamente a continuación, con una panorámica descendente que acude a la contra del movimiento del humo que se alza hacia el cielo de Birkenau. 
Imágenes 09 y 10: La zona gris (Tim Blake Nelson, 2001)

A continuación, regresamos de nuevo al interior de la cámara de gas. En esta ocasión, los sonderkommando pintan de blanco sus paredes ante la atenta mirada de un SS que fuma un cigarrillo al fondo de la escena. Se produce un salto sobre el eje óptico de alejamiento y el cuadro de los trabajadores se amplía considerablemente, generando una suerte de tableau macabro.

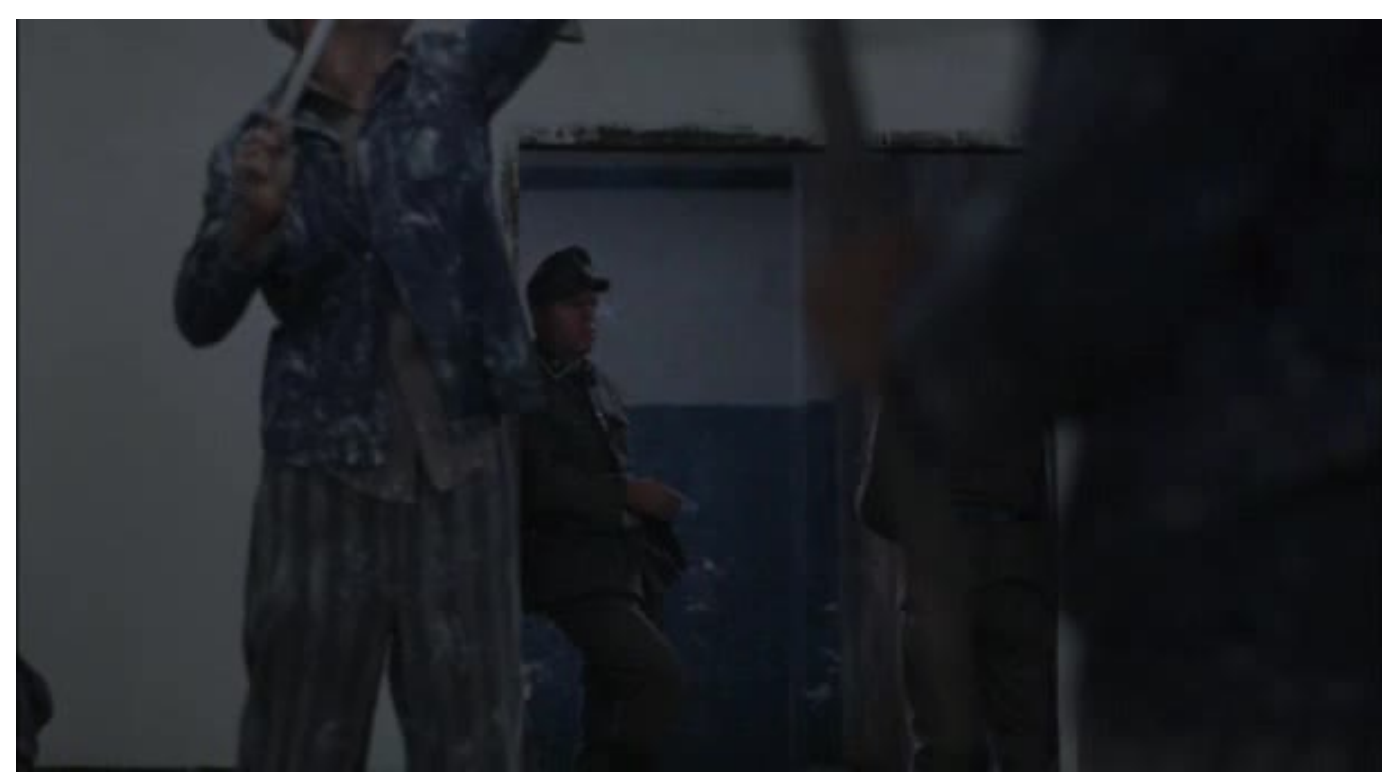




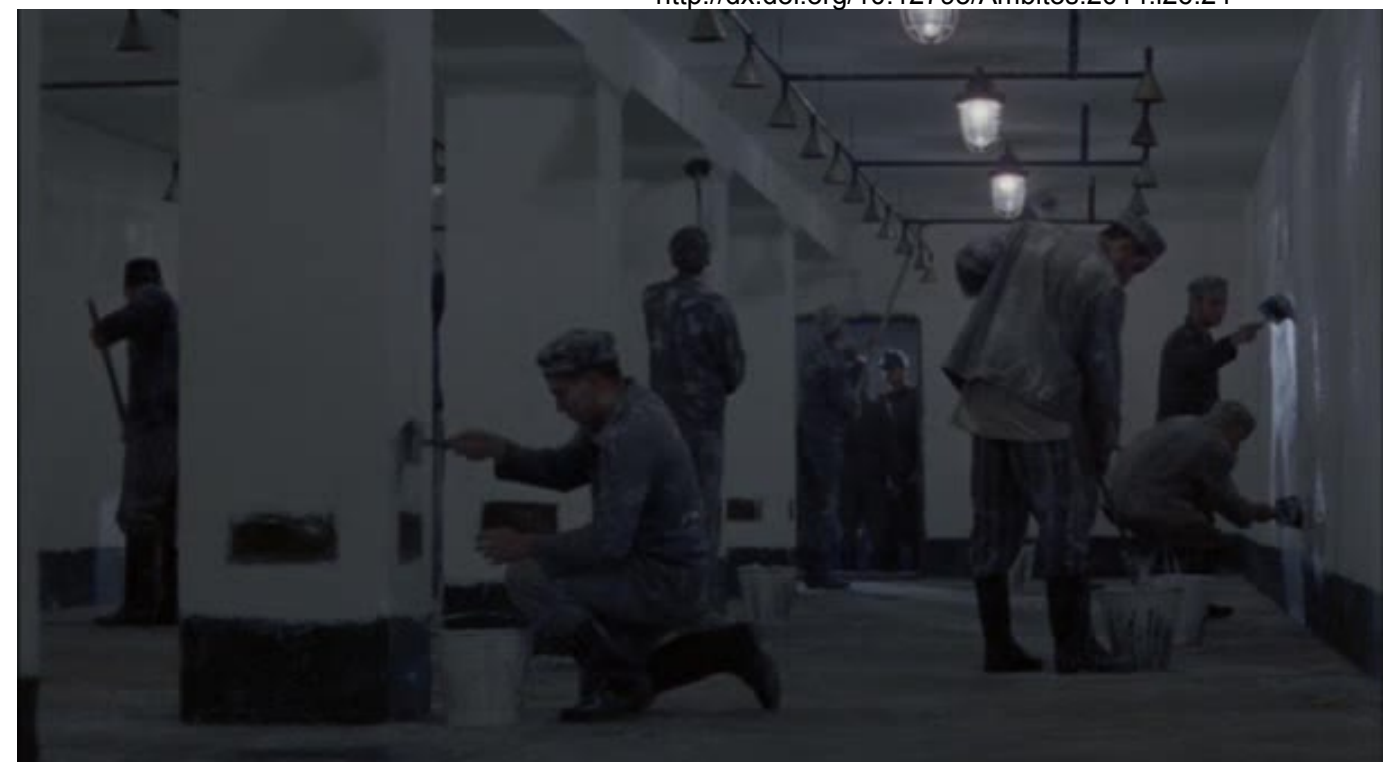

Imágenes 11 y 12: La zona gris (Tim Blake Nelson, 2001)

En primer lugar, la secuencia está completamente desgajada en términos narrativos. No comparece ningún protagonista, ni tiene lugar ningún acontecimiento que haga avanzar la acción. Antes bien, su significado es puramente descriptivo de cara al espectador: nos habla de un proceso, de la elaboración de un cierto trabajo. Los planos están conectados por una suerte de lógica apoyada en el tiempo: mientras se limpian las paredes (panorámica), arden los cadáveres (panorámica), y finalmente (salto de eje óptico) el habitáculo se prepara para una nueva recepción de futuras víctimas.

Retornando a la definición del montaje holocáustico según Didi-Huberman, lo que le interesa a Blake Nelson es potenciar una lectura de la experiencia de las cámaras dentro de la lógica productiva, al menos para la mirada de los Sonderkommando y de los verdugos. Para ellos se trata únicamente de un trabajo[5], que la cámara muestra gracias al distanciamiento de los hombres que lo ejercen, y del movimiento milimetrado con el que se recorre el espacio. Se trata de planos razonablemente extensos (de catorce, nueve, cuatro y siete segundos, respectivamente), con escaso movimiento interno (una mano que desliza una brocha, un cigarrillo que se deja caer...) y con prácticamente ningún rastro de subrayado emocional: ni lágrimas, ni música de fondo, ni rostros. Simplemente una gélida maquinaria de hombres ausentes que realizan una determinada labor, y la huella tecnológica -las chimeneas- de esa labor realizada. También es importante señalar lo que el montaje deja fuera, esto es, lo que Blake Nelson no considera necesario para realizar la "aprehensión de la historia" didihubermanniana: la imagen del propio cadáver, el cuerpo que se consume en el interior de los hornos, las maniobras realizadas sobre la víctima para maximizar su rendimiento económico -extracción de dientes, corte del pelo...

Ahora bien, merece la pena comparar esta presentación con la vivencia estética que Blake Nelson le dedica a las víctimas. Antes de llegar a la mitad del metraje, un tren de judíos húngaros cuya trayectoria hemos ido siguiendo durante la cinta mediante una serie de planos descontextualizados de poca duración -las vías de un tren, una plano subjetivo dentro del vagón...- desemboca finalmente en Auschwitz-Birkenau. Hoffman (David Arquette), uno de los Sonderkommando, protagoniza un violento incidente con un ciudadano que se niega a darle sus pertenencias. Finalmente, los personajes entran en la cámara de gas.

En esta ocasión, el montaje resuelve la entrada en las cámaras de gas mediante un plano secuencia subjetivo, tomado con la cámara al hombro desde una perspectiva ligeramente contrapicada -óptica que corresponde, a su vez, con la mirada de la niña sin nombre (KameliaGrigorova) que protagonizará la segunda parte del relato. 


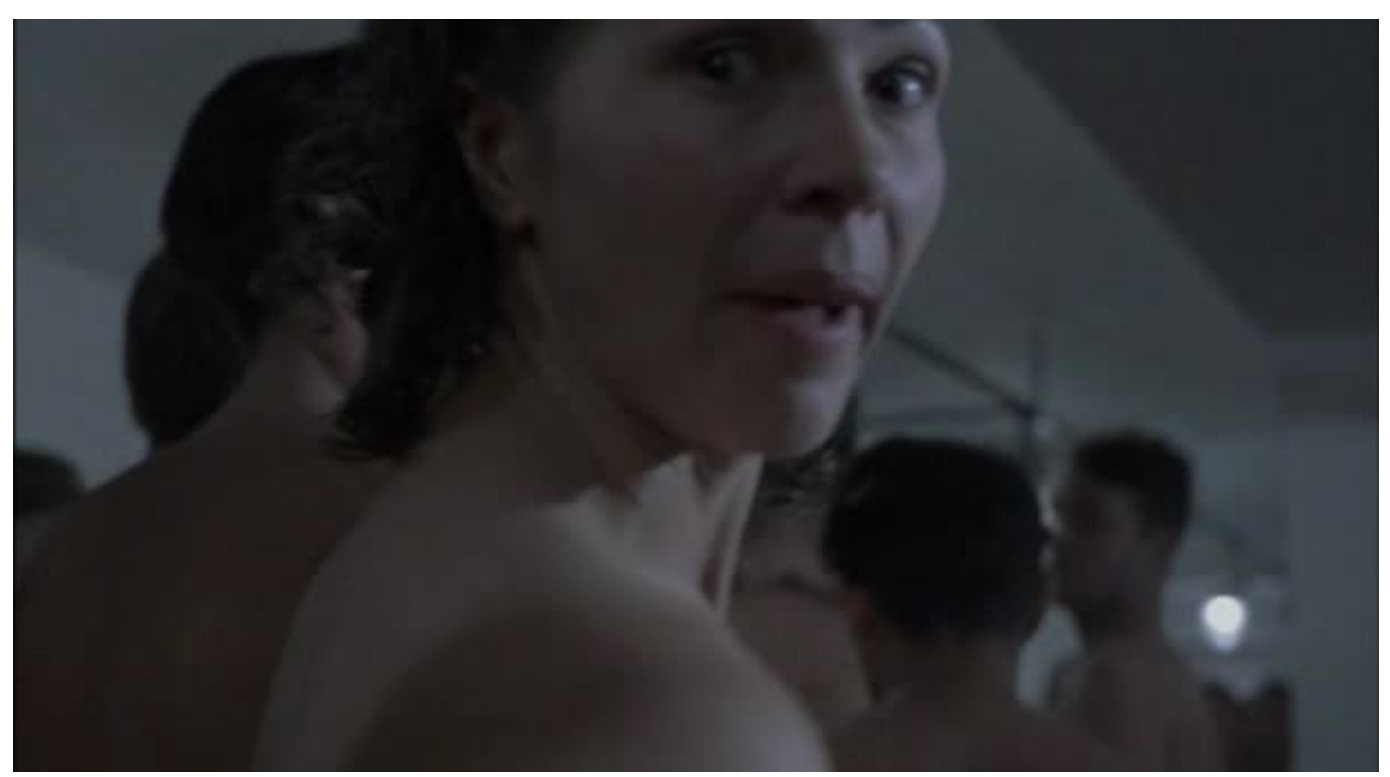

Imágenes 13 y 14: La zona gris (Tim Blake Nelson, 2001)

El montaje volverá a dejar de nuevo fuera del relato la mostración explícita de lo que ocurre con los cuerpos en el interior de la cámara. En su lugar, ofrece dos planos sustitutorios: un rápido inserto de la puerta al ser cerrada y una panorámica de acercamiento al cuerpo atormentado de Hoffman, utilizando únicamente el sonido para sugerir lo que ocurre en su interior: gritos, golpes sobre las paredes, y el constante zumbido de los crematorios filtrándose en el espacio. 


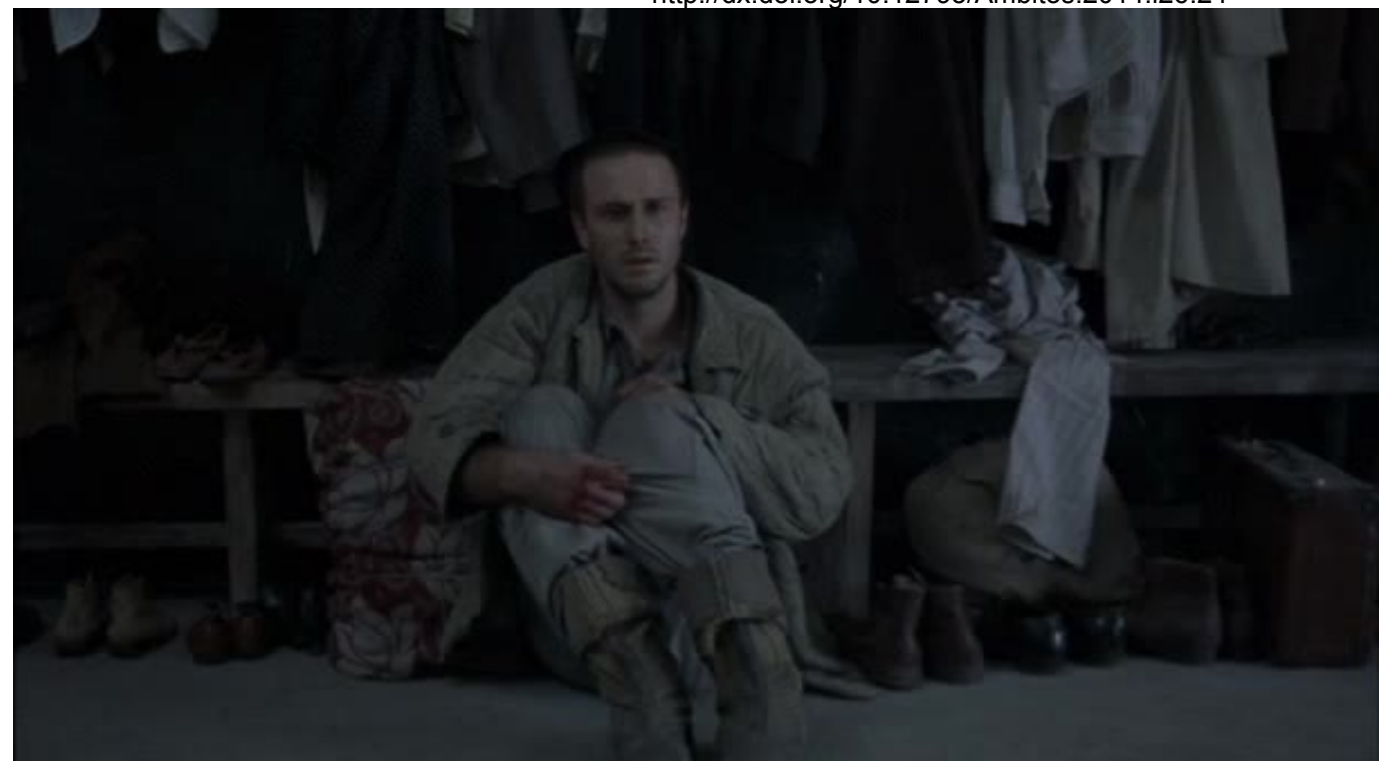

Imágenes 15 y 16: La zona gris (Tim Blake Nelson, 2001)

La división formal entre los dos puntos de vista es relevante, precisamente en cuanto se hace cargo de dos experiencias diferentes. El único plano de entrada de la víctima dura aproximadamente cuarenta segundos más que los cuatro planos destinados a losSonderkommando- y está planteado en oposición al estatismo y a la frialdad que habíamos contemplado. Los recursos para generar una experiencia de inmersión en el espectador se multiplican: miradas directas a cámara, plano subjetivo, ausencia voluntaria de una construcción de plano con referencias pictóricas...

Una vez más, este tipo de montaje puede suponer, para los teóricos de la inefabilidad, un problema experiencial. Por mucho que La zona grisparezca apoyarse en este momento crítico en planos de mayor duración de sabor moderno -planos que rozan la sugerencia de montaje baziniana de la que hablábamos anteriormente-, no es menos cierto que su deuda estética deriva del cine directo y de los tics de representación plenamente postmodernos. Pocos ensayos han enunciado estas críticas con la lucidez que el análisis crítico que Arturo Lozano Aguilar levantó a propósito de La lista de Schindler:

La armoniosa acogida que encuentran en la película todas estas soluciones formales sin hegemonía de una sobre otra implica necesariamente la ausencia de las significaciones que en su día llevaron a postular estos modos de representación frente a otros. Esta característica, que parece permear el universo audiovisual en el que vivimos, ha sido definida por la crítica como una inflación de imágenes vacías, es decir, como un abigarramiento formal que proporcionaría una riqueza superficial de la imagen pero que carecería de cualquier posicionamiento coherente frente a la realidad y su representación. Subyace a esta actitud una incertidumbre estética y una voluntad acumulativa con pretensiones de encontrar una forma apropiada para cada momento sin comprometerse con ninguna de ellas y, mucho menos, con las implicaciones éticas que conllevan (2001: 8889).

La idea enunciada por Lozano Aguilar nos lleva de nuevo a la problemática sobre la verdad en la representación del Holocausto. Sin embargo, nos gustaría esbozar una serie de sugerencias al hilo de ésta cita y de los fragmentos de La zona gris. En primer lugar, parece evidente que los dos puntos de vista trabajados -los Sonderkommando y la propia víctima- no pueden coincidir, o al menos, ser representados de la misma manera. Igualar su mirada sobre las cámaras de gas acabaría generando una indudable aberración teórica, dando por sentado con demasiada rapidez que ambas figuras pertenecen a la misma esfera histórica (6). Frente a esta diferencia, podemos tomar, al menos, dos decisiones formales. La primera está ensayada en el plano secuencia de Good y consistía en generar una tensión mediante un único recurso -el plano secuencia-, en el que se sugirieran distintos puntos de vista o, a la postre, en el que fueran los distintos espacios del encuadre los que generaran la diferencia entre figuras holocáusticas.

La segunda decisión, ensayada en La zona gris, es la modificación del propio lenguaje audiovisual en el interior de la misma película para generar, a su vez, dos efectos estéticos y emocionales distintos. Y, antes de desechar 
maniqueamente como un simple "pastiche" esta opción, deberíamos reflexionar sobre sus posibilidades expresivas y, por qué no decirlo, sobre su conveniencia histórica. En primer lugar, sería necesario preguntarse, contra lo que generalmente se afirma, qué condiciones de verdad o, en el límite, de compromiso ético, hay en un cierto modo de representación determinado. El hecho de que un tipo de montaje "de atracciones" se vincule automáticamente con la manipulación ideológica en favor de una transparencia más o menos moderna no tiene, per se, una mayor o menos garantía ética. Si tomáramos, por ejemplo, una cinta como Irreversible (Irréversible, Gaspar Noé, 2002), podríamos constatar cómo la utilización de largos planos secuencia puede servir para generar mensajes significantes de difuso contenido político, susceptibles incluso de ser interpretados en clave racista u homofóbica (Edelstein, 2003). Antes bien, el montaje no deja de ser una decisión expresiva para hacer cristalizar una cierta experiencia. El hecho de que un director como Blake Nelson decida utilizarlo para hacerse cargo de dos temblores estéticos diferenciados pero históricamente precisos, no tendría por qué significar, a priori, ni una marca de obscenidad, ni de banalización, ni mucho menos de impertinencia histórica.

En nuestro siguiente ejemplo, tendremos ocasión de analizar, a la contra, unos efectos aberrantes generados por el montaje.

\section{LA IMPRESIÓN DEL ARCHIVO O LA PROBLEMÁTICA DEL PRÓLOGO DE AUSCHWITZ (UWE BOLL, 2011)}

Sería demasiado fácil -y sin duda, precipitado- descartar el Auschwitz de UweBoll como un objeto de estudio menor. Ciertamente, la filmografía de su director, así como la línea general de su producción cinematográfica, no parecen ser buenas cartas de presentación para una producción sobre los campos de exterminio. A la contra, nos gustaría proponer que el texto de Boll, con todas sus incongruencias y sus problemas significantes, es especialmente interesante en tanto ofrece una lectura holocáustica que puede ser la respuesta directa de la imagen contemporánea a tantas décadas de mandato iconofóbico de sabor lanzmanniano. Dicho con otras palabras: allí donde se ha puesto el mayor empeño en prohibir -la mostración explícita del Holocausto-, es lógico que surja un deseo de mirar y, consecuentemente, un realizador que decida satisfacer ese deseo. Simplemente por esa razón, ya sería necesario rastrear el trabajo de Boll para poder entablar sobre él un debate estético e histórico.

Por lo demás, el funcionamiento de Auschwitz es, en principio, francamente interesante. El director genera una narración en cuatro bloques bien diferenciados: una declaración de intenciones con la que se dirige al objetivo de la cámara en alemán y en inglés, dos bloques de entrevistas a jóvenes alemanes en su instituto que demuestran un más que deficitario conocimiento de lo ocurrido en los campos y, entre ellos, una ficcionalización del proceso de exterminio en los términos más brutales que hasta ahora se han construido en la pantalla.

Si bien el estudio completo de la obra escaparía, con mucho, a los objetivos del presente trabajo, sin duda puede ser interesante utilizarla para hacerla chocar con los dos grandes problemas que hemos esbozado: la relación entre el montaje, la etiqueta de "verdad" en las narraciones del Holocausto y la problemática de las cámaras de gas. Comencemos, por lo tanto, con la "declaración de intenciones" del director.

La cinta arranca con un hombre que comparece ante el espectador. Y que, en un ejercicio de meta-reflexión cinematográfica, se introduce en el relato para justificarlo. Sin embargo, mientras enuncia su responsabilidad en el proyecto, se produce una erosión sobre ese primer plano: una imagen de archivo -a color- situada en uno de los campos de exterminio:

Boll: Hola, soy UweBoll, el escritor, productor y director de Auschwitz. Soy el responsable de la película. 

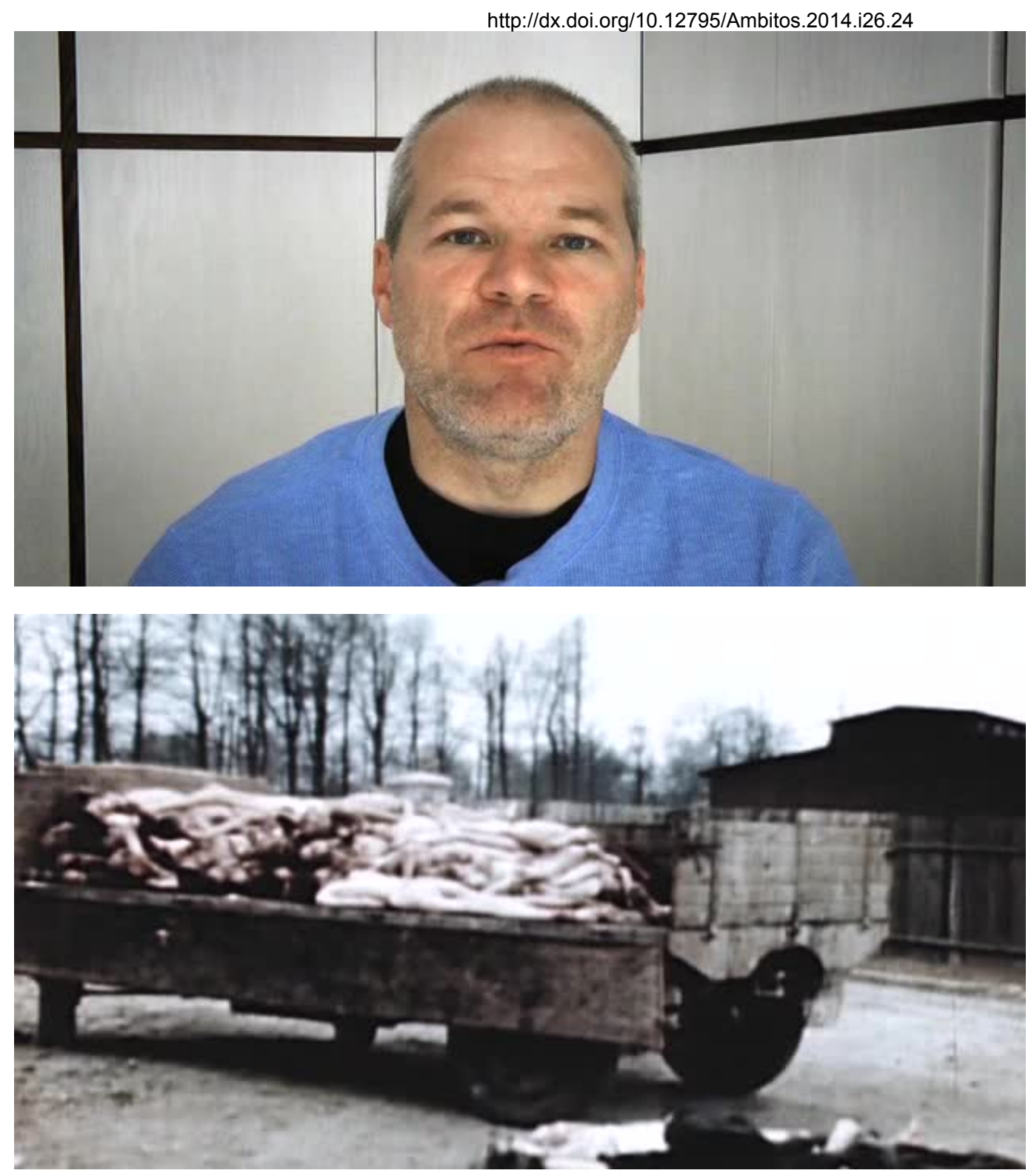

Imágenes 17 y 18: Auschwitz(UweBoll, 2011)

El discurso de Boll se levanta, como ya hemos dicho, en dos lenguas: el alemán y el inglés. Cada vez que el director cambia de lenguaje, se introduce uno de esos planos de archivo. Resulta interesante que toda la presentación se genere sobre esa incomodidad de la lengua, ese doblez del lenguaje en el que comparecen tanto el lenguaje en el que se perpetra el crimen (Klemperer, 2001) como el lenguaje hegemónico en el momento del rodaje. Lo que más nos interesa ahora, sin duda, es la extraña función de "separador" en la que Boll utiliza las imágenes de archivo. Hay dos efectos inmediatos en su posición: el primero es el de "cita" o "referencia" a la parte más extrema de una imaginario icónico de nuestra Historia reciente: conocemos esas imágenes -las pilas de cadáveres, los camiones cargados, los rostros esqueléticos- y se han convertido en parte integrante de nuestro universo icónico. Son, por lo tanto, un elemento que pese a su contenido siniestro, ya ha sido integrado en nuestro paisaje icónico (Zemel, 2003; Bohm-Duchen, 2003). Del mismo modo, y en un segundo nivel, la inserción de dichas imágenes funciona como una garantía de verdad, un elemento que inviste de autoridad las palabras de Boll en tanto las atraviesa en el montaje. El cadáver comparece, silencioso, allí donde el director proclama, de manera explícita y de manera comparativa, el grado de verdad que pretende conseguir en su representación.

Boll: Han pasado setenta años y el mundo ha escogido olvidar de nuevo. Hay otros genocidios, como en Rwanda o en Srbenica, Darfur o el Congo, y creo que era el momento de hacer una película como esta, que realmente mostrara lo que ocurrió, lo que era Auschwitz. Era como una fábrica de carne, la gente moría asesinada como nosotros matamos hoy en día pollos o cerdos o vacas. No hubo héroes, no hubo un Dios que les ayudara, ni historias especiales. Y las películas que han hecho hasta ahora hablan de los héroes: gente que intenta matar a Hitler como SophieScholl, o la gente que ayudó a los judíos como en La lista de Schindler (...) y 
creo que ya era el momento de hacer algo que omitiera toda esa parte y mostrara lo que realmente ocurrió, el horror.
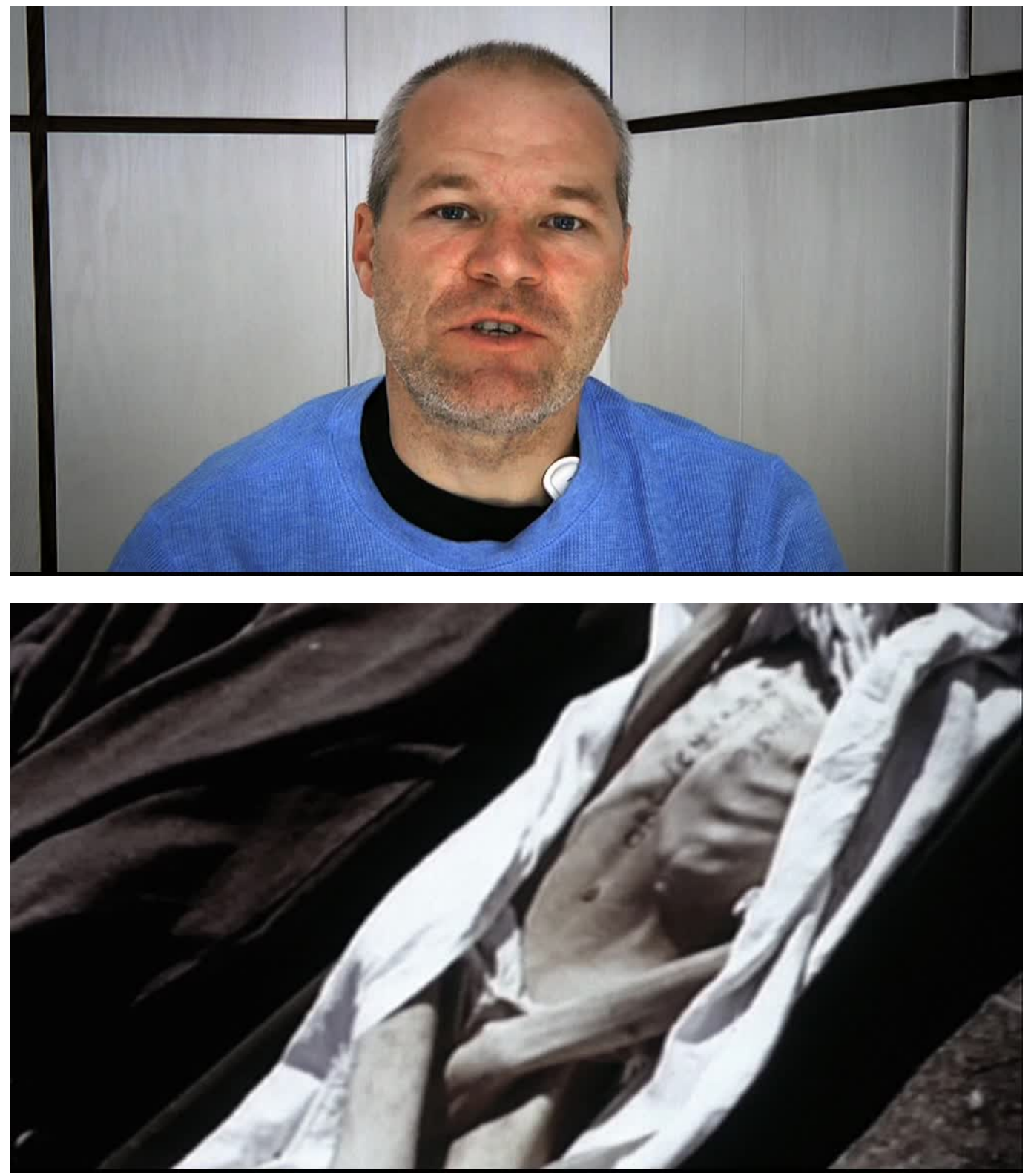

Imágenes 19 y 20: Auschwitz(UweBoll, 2011)

Al margen de los muchos problemas históricos y ontológicos que plantea la definición de Boll o, como ya hemos visto, la pura dificultad de definir "qué es Auschwitz", a nivel de montaje hay un hecho que desmonta por completo su introducción: las imágenes insertadas no pertenecen a las bobinas rodadas por los soviéticos en la liberación de los campos. De hecho, las escasas imágenes que tenemos del interior de Auschwitzdespués de la liberación son, en su gran mayoría, imágenes propagandísticas, modificadas a su conveniencia por distintos técnicos del ejército rojo (7), que por lo demás, no corresponden a las utilizadas por Boll.

¿De dónde provienen, por lo tanto las imágenes que el director utiliza como garantes de su verdad en el concepto de Auschwitz? La clave para localizarlas se encuentra en su propia textura y en el uso del color: se trata de película la película Eastmancolor que se utilizó para rodar la liberación de Dachau y de Buchenwald, probablemente vinculada de alguna manera a los equipos de Georges Stevens (Didi-Huberman, 2004: 215216). El uso de la descontextualización histórica de dichas imágenes puede tener múltiples interpretaciones: quizá la voluntad de Boll de "impactar" en un público más joven le llevó a prescindir voluntariamente del blanco y negro, quizá se trató de un ejercicio de alejarse de ese blanco y negro que tanto había molestado a los críticos de Spielberg (Lozano Aguilar, 2001, 100-102), quizá simplemente quería generar una conexión visual con sus propias imágenes de Auschwitz, imágenes que se caracterizarán por una paleta compuesta por colores suaves y gélidos. En cualquier caso, el problema de Boll es de corte historiográfico -y, consecuentemente, ético. Su 
incursión no tiene tanto que ver con la idea de elevar a lo universal una serie de fragmentos audiovisuales -un "icono total del Holocausto" como ya es, pongamos por caso, la fotografía del niño con los brazos alzados en Varsovia-, sino antes bien, con el hecho de concretizar a costa de su manipulación -insertar en un discurso sobre Auschwitz-, aquello que debería ser, en todo caso, una pieza significante concreta, delimitada, específica. Lo que Boll acaba achacando en su discurso a la juventud alemana -no conocen los datos, confunden las fechas y las cifras-, emerge en el interior de su propio discurso por una mala utilización de las imágenes. Como el lector podrá comprobar, no estamos defendiendo ningún tipo de prohibición con la inclusión de esos elementos significantes, sino antes bien, queremos hacer notar que en el momento en el que se citan como injertos textuales, su límite queda impuesto por el rigor historiográfico, o si se prefiere, por cómo el montador decide que esas imágenes deben hablar.

\section{CONCLUSIONES}

Hace unos años, Didi-Huberman afirmó en una de sus conferencias:

Intentar hacer una arqueología siempre es arriesgarse a poner, los unos junto a los otros, fragmentos de cosas que han sobrevivido; cosas necesariamente heterogéneas y anacrónicas puesto que vienen de lugares separados y de tiempos desunidos por lagunas. Ese riesgo tiene por nombre imaginación y montaje (2013: 1819). (8)

En el caso de la reconstrucción del Holocausto, la imaginación no tiene por qué ser incompatible con la verosimilitud histórica ni con la pertinencia ética del discurso -ahí está, por ejemplo, el comic Maus (Spiegelman, 2007)-, ni muchísimo menos con el compromiso que éste adquiere con la verdad, o mejor dicho, con su búsqueda. De hecho, al igual que el montaje, son herramientas indispensables e inseparables para llegar a dar luz a los rincones más oscuros de la herencia de los campos.

Nuestra investigación sigue, por lo tanto, abierta. Hemos puesto en duda la utilización de tres rasgos concretos, pero una teoría completa sobre el montaje de materiales holocáusticos debería encarar, por ejemplo, el uso del montaje alterno entre distintos contextos históricos -ya presente en obras como El prestamista (ThePawnbroker, Sidney Lumet, 1964), pero desarrollada con más fuerza en obras contemporáneas como La llave de Sarah (Elle s'appelait Sarah, GillesPaquet-Brenner, 2011)-, así como las posibilidades de incorporar efectos digitales para recrear o sugerir los escenarios en los que ocurrieron las distintas fases de la tragedia. Se trata de algunos aspectos que encararemos en el futuro, pero que no pueden ser despejados sin asumir previamente que, una vez demolidos los tópicos sobre la inefabilidad, la necesidad de decir -con todas sus aristas, con todos sus problemas y sus contradicciones- se impondrá con más fuerza todavía. Nos gustaría, por lo tanto, sumarnos a esa opinión vertida por David Grossman (9) que señalaba que el artista que se enfrentaba con el Holocausto necesitaba llegar tan lejos como fuera posible para poder construir, aun a riesgo de equivocarse, un punto de vista cada vez nuevo, coherente y complejo.

\section{REFERENCIAS BIBLIOGRÁFICAS}

AAVV (2007): La forma que piensa. Tentativas en torno al cine ensayo. Navarra: Festival internacional de cine documental de Navarra.

AGAMBEN, G. (2005): Lo que queda de Auschwitz: El archivo y el testigo. Homo Sacer III.Valencia: Pre-Textos.

BAUER, Y. (2001): Rethinking the Holocaust. Londres: Yale University Press.

BAUMAN, Z. (2010): Modernidad y Holocausto. Madrid: Sequitur

BAZIN, A. (2001).: ¿Qué es el cine? Madrid: Editorial Rialp.

BOHM-DUCHEN, M.: Emblems of Atrocity: Holocaust Liberation Photographs. En AAVV (2003): Image and Remembrance. Representation and the Holocaust. Indianapolis: Indiana University Press, pp.201-219.

BROWNING, C. (2002): Aquellos hombres grises: El batallón 101 y la Solución Final en Polonia. Barcelona: Edhasa. 
DIDI-HUBERMAN, G. (2004): Imágenes pese a todo. Memoria visual del Holocausto. Barcelona: Paidós.

DIDI-HUBERMAN, G.: Cuando las imágenes tocan lo real. En AAVV (2013): Cuando las imágenes tocan lo real. Madrid: EdicionesdelCírculo de BellasArtes, pp. 7-36.

E. LIPSTADT, D. (2006): History on Trial: My day in court with a Holocaust denier. Nueva York: Harper.

EDELSTEIN, D. : "Irreversible Errors. Gaspar Noe'scinematic Rape". Slate, Edición on-line disponible en http://www.slate.com/articles/arts/movies/2003/03/irreversible_errors.html [Consultado en Agosto de 2013].

FONT, D. (2002): Paisajes de la modernidad. Barcelona: Editorial Paidós.

FRIEDLÄNDER, S. (2009): El tercer Reich y los judíos (II Vol.). Madrid: Editorial Galaxia Gutenberg.

FRODON, J.: Intersecting Paths. En AAVV (2010): Cinema \&TheShoah. An Art confronts the Tragedy of the Twentieth Century. Albany: State University of New York.

G. FINKELSTEIN, N. (2003): The Holocaust Industry. Reflections on the Explotiation of Jewish Suffering. Nueva York: Verso.

GERSHENSON, O. (2013): The phantom Holocaust: Soviet Cinema and Jewish Catastrophe. New Brunswick: Rutgers University Press.

GOLDHAGEN, D. (1997): Los verdugosvoluntarios de Hitler. Madrid: Taurus.

HAGGITH, T.: Filming the Liberation of Bergen-Belsen. En AAVV (2005): Holocaust and the moving image: Representation in Film and Television since 1933. Londres: Wallflower press, pp.33-49.

HEIDEGGER, M. (1995): Caminos del bosque. Madrid: Alianza editorial.

HILBERG, R. (1993): Perpetrators, Victims, Bystanders: The Jewish Catastrophe, 1933-1945. Nueva York: HarperPerennial.

HILBERG, R. (2005): La destrucción de los judíos europeos. Madrid: Akal.

INSDORF, A. (2002): Indelible Shadows: Film and the Holocaust. Nueva York: Cambridge University Press.

J. EVANS, R. (2001): Lying about Hitler: History, Holocaust and the David Irving Trial. New York: Basic Books.

JACOBS, S.: "Hitchcock, the Holocaust and the Long Take. Memory of the camps".Arcadia - International Journal for Literary Studies.Vol. 45 (abril de 2011), №2, pp. 265-276.

KERNER, A. (2011): Film and the Holocaust: New Perspectives on Drama, Documentaries and experimental films. Continuum: Nueva York.

KIERKEGAARD, S. (1997): Migajas filosóficas o un poco de filosofía. Madrid: Trotta.

KLEMPERER, V. (2001): LTI: La lengua del III Reich. Apuntes de un filólogo . Barcelona: Editorial Minúscula.

KRACAUER, S. (2001): Teoría del cine. Barcelona: Paidós.

LANZMANN, C. (2003): Shoah. Madrid: Arena Libros.

LANZMANN, C. (2011): La liebre de la Patagonia. Barcelona: Seix Barral.

LOZANO AGUILAR, A. (2001): La lista de Schindler. Estudio Crítico. Barcelona: Paidós.

MORENO CLAROS, L. (2002): Martin Heidegger. El filósofo del ser. Madrid: Edaf.

MORENO FELIU, P. (2010): En el corazón de la zona gris. Una lectura etnográfica de los campos de Auschwitz . 
Madrid: Ed. Trotta.

MORENTE, F.: La universidad alemana y la construcción del III Reich. En AAVV (2004): Pensar después de Auschwitz. Mataró: El viejo topo.

NYISZLI, M. (2011): Fui asistente del Doctor Mengele. Cracovia: Editorial del Museo Auschwitz.

POGGIO, P. (2006): Nazismo y revisionismo histórico. Madrid: Akal.

QUESADA, J. (2008): Heidegger de camino al Holocausto. Madrid: Biblioteca Nueva.

QUINTANA, A. (2003): Fábulas de lo visible. El cine como creador de realidades. Barcelona: El acantilado.

REYES MATE (2003): Por los campos de exterminio. Madrid: Anthropos.

RODRÍGUEZ SERRANO, A.: Nuevas perspectivas teóricas sobre las representaciones fílmicas del Holocausto: Análisis textual sobre el rol del testigo de tercer grado como protagonista. En AAVV (2012): IV Congreso Internacional Latina de Comunicación, La Laguna, Diciembre de 2012.

RODRÍGUEZ SERRANO, A.: "La muerte que habla: La escritura del Holocausto en La zona gris". Revista Trama\&Fondo. № 35 [Diciembre de 2013. En prensa].

SPIEGELMAN, A. (2007): Maus. Barcelona: Mondadori.

T. GROSS, J. (2001): Neighbors: The Destruction of the Jewish Community in Jedwabne. Nueva York: Princeton UniversityPress.

SÁNCHEZ-BIOSCA, V. (1996): El montaje cinematográfico. Teoría y análisis. Barcelona: Paidós.

SÁNCHEZ-BIOSCA, V. (2006): Cine de Historia, Cine de Memoria: La representación y sus límites . Barcelona: Cátedra.

STRUK, J. (2004): Photographing the Holocaust: Interpretations of the Evidence. Nueva York: I.B. Tauris. SUSSEX, E.: "The Fate of F3080". Sight and Sound, Nº 53 (1984): 92-97.

SWIEBOCKI, H. (2000): Auschwitz, 1940-1945 (Vol IV: The Resistance Movement). Cracovia: Editorial del Museo Auschwitz.

VATTIMO, G. (2002): Introducción a Heidegger. Barcelona: Gedisa.

WAJCMAN, G.: “De la croyancephotographique”. Les Tempsmodernes, LVI (2001), № 613, pp. 47-83.

WIESEL, E. (1984): Against Silence (III Vol.). Nueva York: Irving Abrahamson

ZEMEL, C.: The uses and abuses of photography in Holocaust-Related Art. En AAVV (2003): Image and Remembrance. Representation and the Holocaust. Indianapolis: Indiana University Press, pp.220-234.

(1) La polémica de la relación de Wiesel con respecto a la mostración del Holocausto todavía no ha sido lo suficientemente estudiada y no hay ninguna obra que analice detenidamente los distintos aspectos de la misma. Los textos originales pueden consultarse en la compilación Wiesel, 1984, y parte de los frutos de su reflexión quedarían cristalizados, por ejemplo, en Insdorf, 2002. Del mismo modo, las críticas más feroces hasta el momento están disponibles en G. Finkelstein, 2003: 45.

(2) El caso más célebre y polémico se encuentra probablemente en La lista de Schindler (Schinder'sList, Steven Spielberg, 1993), en la secuencia en la que el director genera una tensión entre unas duchas y las auténticas 
cámaras de gas, decidiéndose finalmente por la primera opción.

(3) La historia de las representaciones holocáusticas en los países del bloque soviético está todavía por hacer, debido a las enormes dificultades que los investigadores nos topamos a la hora de conseguir el material generado -y censurado- por los distintos estudios y organizaciones. En cualquier caso, se pueden consultar el muy recomendable Gershenson, 2013.

(4) Hemos tenido la ocasión de dedicar un artículo monográfico a esta película, estudiando las relaciones entre inefabilidad y representación, actualmente en prensa, y que puede ser consultado bajo la referencia bibliográfica -de momento, pendiente de su confirmación definitiva- en RODRÍGUEZ SERANO, 2013.

(5) Ilusión que, a su vez, se reforzará con la última línea de la película: Y así es como el trabajo continúa. Del mismo modo que en Good se llegaba al descubrimiento de la verdad con el Es real, Blake Nelson subraya que ese "ser real" se refiere a un proceso mecánico de borrado de huellas y destrucción de cuerpos, generado gracias a una lógica industrial.

(6) Este terrible error de equiparar sufrimientos y puntos de vista en el interior del Holocausto no sólo es la causa del terrible mensaje unificador que subyace detrás de la muy discutible El niño del pijama a rayas, sino que también, dicho sea de paso, es la base de toda una escuela negacionista vinculada con la extrema derecha (Poggio, 2006). La necesidad de generar claras divisiones entre los puntos de vista y la supuesta diferencia entre víctimas y verdugos -en la que los cuales, la zona gris establecida por los Sonderkommando es un problema antropológico (Moreno Feliu, 2010) y filosófico (Agamben, 2005) de primer orden-, especialmente después del enfrentamiento legal entre la historia Deborah Lipstatd y el negacionista David Irving (J. Evans, 2001; E. Lipstadt, 2006).

(7) Dicha colección de imágenes se puede contemplar en el documental TheLiberation of Auschwitz(Die Befreiung von Auschwitz, Irmgard von zurMühlen, 1986). En dicho documental se introducen, de manera muy sutil, algunas informaciones sobre la manipulación y reconstrucción con fines ideológicos, si bien todavía estamos muy lejos de tener un estudio exhaustivo al respecto. Del mismo modo, dichas imágenes iban a componer los últimos minutos de Memory of theCamps, el documental con el que abríamos nuestro trabajo. Sin embargo, y por razones todavía sin aclarar, las imágenes rusas no se utilizaron.

(8) La cursiva pertenece al autor.

(9) Declaraciones recogidas en la instalación Centro de Reflexión de YadVashem-Jerusalem, dentro del aparatado ¿Debe la representación del Holocausto en el arte tener límites impasables?

\section{Breve semblanza del autor}

Aarón Rodríguez Serrano es Doctor en Comunicación Audiovisual y Profesor Titular de la Universidad Europea de Valencia. Miembro de la Asociación Española de Historiadores del Cine (AEHC), ha publicado varios libros, siendo el más reciente Apocalipsis pop! El cine de las sociedades del malestar (Ed. Notorius, 2012). Participa como crítico y analista de manera regular en revistas comoShangriaLa Textos Aparte, Detour, El rayo verde, Cine Divergente...

Ámbitos. Revista Internacional de Comunicación, n.26, año 2014, tercer trimestre (otoño).

Recibido: 23/6/2014

Aprobado: 29/8/2014 